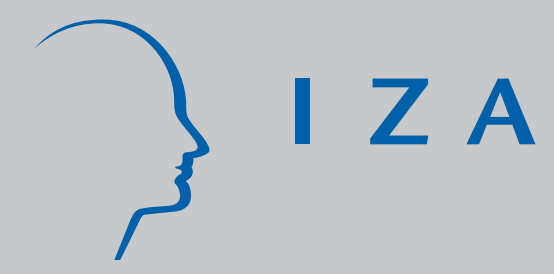

IZADP No. 1650

J ob Displacement Penalties in J apan

Michael Bognanno

Lisa Delgado

July 2005 


\title{
Job Displacement Penalties in Japan
}

\author{
Michael Bognanno \\ Temple University \\ and IZA Bonn \\ Lisa Delgado \\ Temple University
}

\section{Discussion Paper No. 1650 \\ July 2005}

IZA

P.O. Box 7240

53072 Bonn

Germany

\author{
Phone: +49-228-3894-0 \\ Fax: +49-228-3894-180 \\ Email: iza@iza.org
}

\begin{abstract}
Any opinions expressed here are those of the author(s) and not those of the institute. Research disseminated by IZA may include views on policy, but the institute itself takes no institutional policy positions.
\end{abstract}

The Institute for the Study of Labor (IZA) in Bonn is a local and virtual international research center and a place of communication between science, politics and business. IZA is an independent nonprofit company supported by Deutsche Post World Net. The center is associated with the University of Bonn and offers a stimulating research environment through its research networks, research support, and visitors and doctoral programs. IZA engages in (i) original and internationally competitive research in all fields of labor economics, (ii) development of policy concepts, and (iii) dissemination of research results and concepts to the interested public.

IZA Discussion Papers often represent preliminary work and are circulated to encourage discussion. Citation of such a paper should account for its provisional character. A revised version may be available directly from the author. 
IZA Discussion Paper No. 1650

July 2005

\section{ABSTRACT}

\section{Job Displacement Penalties in Japan*}

The costs of job displacement are examined on a sample of Japanese workers successfully provided job placement services from 2000 to 2003, a period of economic stagnation and structural change in Japan. We find that displaced workers suffer a loss of approximately $\$ 1,100$ for each additional year of age. Workers also incur a large penalty when they change industries after being displaced. The age-earnings loss relationship is consistent with the operation of a delayed compensation scheme in large firms.

JEL Classification: J31, J41, J63, J65

Keywords: $\quad$ job displacement cost, Japan

Corresponding author:

Michael Bognanno

Department of Economics (004-00)

Temple University

Philadelphia, PA 19122

USA

Email: bognanno@temple.edu

\footnotetext{
* We thank Charles Swanson, two anonymous referees and seminar participants at Temple University for their comments. The support of a Marie Curie Fellowship for the Transfer of Knowledge is gratefully acknowledged by Bognanno.
} 


\section{Introduction}

Structural changes in the Japanese economy and sluggish growth in the 1990s and beyond have imposed hardships on workers with both social and economic consequences. ${ }^{1}$ The high cost of job displacement was one aspect of the economic consequences. In this paper we use a unique data set from a job placement firm to study the impact of job displacement on the wages of workers in large firms and to quantify the impact of age, gender, education, tenure, hierarchical level, initial firm size (employment), days of unemployment and industry change on job displacement penalties. During the sample period from 2000 to 2003, we find evidence of job displacement penalties that increase strongly with age at a rate of approximately $\$ 1,100$ per year. We also find large penalties associated with industry change and the number of days spent in job search when these are treated exogenously.

Between 1990 and 2003, the overall unemployment rate in Japan crept up from $2.1 \%$ to $5.3 \%$. Despite a worsening labor market, older, full-time male workers with significant tenure were largely shielded from unemployment in the 1990s through the buffering effect of traditional human resources

\footnotetext{
${ }^{1}$ One stark indicator of social crisis is that suicides among men have risen seventy percent over the past ten years, with the biggest increases affecting men in their forties and fifties. Japan has the highest suicide rate in the developed world, more than twice that of the US. News reports attribute the increase to the hardship imposed on men in their forties and fifties by the restructuring of the economy [Pesek 2003]. We find that on an annual income basis, the oldest workers bear the highest job separation cost. On a career basis, making the assumptions that the separation cost reflected by the initial change in annual income remains fixed in real terms and retirement occurs at age 60, workers in their forties bear the highest cost.
} 
practices. These practices include reducing hours and overtime pay, reducing the hiring of college graduates, and transferring workers to other firms either temporarily (shukko) or permanently (tenseki). ${ }^{2}$ While the media has deemed lifetime employment over, ${ }^{3}$ Kato [2001] argues against this notion. ${ }^{4}$ He documents that for workers from thirty to forty-four with five or more years of firm tenure there was only a very slight drop in ten year retention rates between the two periods of $1977-87$ and $1987-97 .{ }^{5}$ Lifetime employment, always something of a misnomer, can not be said to have ceased for the older workers with substantial tenure.

Nevertheless, concern continues to be expressed over the continued retention of the relatively privileged core workers, along with pessimism about their ability to leave the secondary labor market once unemployed. ${ }^{6}$ While

\footnotetext{
${ }^{2}$ See Kato [2001] for applications of these practices in firm case studies.

${ }^{3}$ The excerpt below from the Asahi Shinbun article by Nakagawa, Nishizaki and Kamiya [2002] is illustrative of the coverage given in newsprint to the circumstances faced by Japanese workers. The article states: Now that the lengthy recession has all but put an end to the lifetime employment system, many corporations have begun taking a long hard look at their workers to determine their actual market value, in an effort to restructure.

${ }^{4}$ Genda and Rebick [2000] maintain that job protection strengthened in the past decade in Japan and that institutional practices changed slowly relative to the pace of change in the labor market.

${ }^{5}$ Kato's data also show that stable retention rates did not hold for all workers in Japan. For workers from twenty-five to twenty-nine, regardless of tenure, and for workers from thirty to forty-four with less than five years of tenure, retention rates fell.

${ }^{6}$ Fujiki, Nakada and Tachibanaki [2001] state: From the viewpoint of the core Japanese workers, typically full-time male workers who have accumulated firm-specific skills through on-the-job training, their relatively favorable employment opportunities may not be sustained during the current recession, and once they lose their position they must stay in the secondary labor market forever.
} 
the first concern over core worker retention rates has yet to be empirically justified, the second concern may have some validity. Our data document the high cost of job displacement for workers from large, well known Japanese firms and the movement to smaller firms for workers upon re-employment. The results give some credibility to the concern expressed over the consequences facing workers that fall from large firms into the secondary labor market.

The literature on job displacement is large and the effects of job displacement on wages have been well documented in the US. ${ }^{7}$ Earnings have been estimated to fall between 15 and 40 percent and these losses increase with both firm tenure and labor market experience [Topel, 1993]. Earning losses were shown by Ruhm [1991] and Jacobsen, LaLonde and Sullivan [1993] to persist four and five years after job displacement. Tenure in the initial job increases earnings in both initial and new jobs but is valued less in the new employment [Addison, 1989; Kletzer, 1991]. Farber [1993] found job displacement penalties to increase by $1 \%$ for every year of firm tenure. Poor labor market conditions and workers changing industries also increase job displacement penalties.

In the only study of job displacement in Japan of which we are aware, Abe, Higuchi, Nakamura, Kuhn and Sweetman [2002] review features of the Japanese and Canadian labor markets and analyze the incidence and consequences of job displacement in Japan and Canada. They find median unemployment durations resulting from job displacement in Japan of less than two months in the middle 1990s. Further, they find virtually no impact on

\footnotetext{
${ }^{7}$ For surveys of this literature see Farber [1996], Fallick [1996] and Hamermesh [1989].
} 
mean wages from job displacement for workers under about 50 years of age in Japan. Only $8.7 \%$ of displaced Japanese men and $4.3 \%$ of Japanese women faced wage reductions greater than $30 \%$. Large wage increases in Japan were also uncommon. Only $2 \%$ of men and $3 \%$ of women had gains over $30 \%$. Job displacement cost increased with age in Japan. For men over 55, mean wages fell 10-15\%. In contrast with Canadian workers under 55, displaced Japanese workers had shorter unemployment spells and were less likely to have large wage reductions. At the same time, because displacement costs rise more strongly with age in Japan than in Canada, more senior Japanese workers experience greater hardships from displacement than Canadian workers.

This study contributes to what is known about the costs of job displacement in Japan. The study by Abe et al. was conducted on job displacements that took place in 1995. GDP was growing at 2.4\% in 1995 and unemployment stood at $3.2 \%$. During our sample period from January 2000 to May 2003, GDP grew at an average annual rate of only $1.5 \%$ and unemployment averaged $4.8 \%$. Though our data is smaller in scope and size that of Abe et al., it is more recent and covers period of greater economic stagnation. We also explore factors that influence job loss penalties that have not been studied. Additionally, though firm tenure was not available to Abe et al. and is also not available in the data that we were supplied, we impute tenure based on a national survey of Japanese workers that provides mean tenure broken down by year, industry, gender, educational level, firm size, and five year age categories. Hence, we can examine the role of tenure on displacement penalties.

The following section of the paper discusses theory relevant to job dis- 
placement. Section 3 describes the data. Section 4 presents the empirical results and conclusions follow in section 5 .

\section{Theory}

It is tempting to think about the primary sector of the Japanese labor market in terms of Lazear's [1979] well-known model of delayed compensation in which wages and the marginal product of workers are not equal. ${ }^{8}$ When the opportunity for long-term employment exists, the delayed compensation model suggests that it may be beneficial to underpay workers relative to their marginal product early in their careers and overpay them later. This compensation scheme is hypothesized to have desirable consequences because workers are provided with the incentive to exert enough effort to remain in the employment of the firm throughout their career.

The Japanese labor market may be relatively well suited to the delayed compensation model for two reasons. The conditions necessary for a firm to offer a delayed payment contract exist to a greater extent in Japan than in the US because mandatory retirement provisions are legal in $\operatorname{Japan}^{9}$ and because

\footnotetext{
${ }^{8}$ In an in Asahi Shinbun article, Nakagawa, Nishizaki and Kamiya [2002] describe an employment relationship that corresponds to the delayed compensation model. The article states: Under this system [the lifetime employment system], workers are normally underpaid and overworked in their early years and only reap the rewards when their salaries surge in their mid-40s.

${ }^{9}$ Mandatory retirement is an important part of the employment contract in the Japanese system [Clark and Ogawa, 1992]. Since April of 1998, the earliest age at which mandatory retirement may be imposed is 60 [Abe, Higuchi, Nakamura, Kuhn and Sweetman, 2003].
} 
long-term employment contracts are more prevalent in Japan. ${ }^{10}$ Long-term employment contracts existed for many workers in Japan, particularly at the larger firms such as those represented in our data.

One implication of Lazear's model is that since young workers are underpaid relative to the marginal product they could earn in the market and old workers are overpaid relative to their market wage, older workers with more years of firm tenure should experience larger reductions in pay as a result of involuntary job separation. Indeed, young workers with little experience at the firm have market wages above their current compensation, assuming that they entered into a delayed compensation contract. Even if these contracts became more difficult to obtain for young workers and they were paid according to their marginal product prior to separation, older workers should still have greater job displacement penalties than younger workers.

More generally, there are several theories relating to the cost of job separation. Fallick [1996] notes four reasons to expect lower wages for displaced workers than their non-displaced counterparts: the loss of specific human capital, the loss of a superior job match, the loss of possible union or industry wage premiums, and the loss of seniority. These factors also link the cost of job separation to job tenure. Assuming that both specific human capital

\footnotetext{
${ }^{10}$ Hashimoto and Raisian [1985] note that job attachment is greater in Japan than in the United States. Indicative of this, both retention rates and years of experience on the job are greater in Japan. Japanese workers also hold fewer new jobs over their lifetime than American workers. They observe that tenure is longer for workers in larger firms in both Japan and the US. However, in Japan small firms also show evidence of strong employee-employer relationships. Additionally, they find that growth rates of earnings attributable to tenure are much greater in Japan than in the United States.
} 
and the quality of the job match increase with job tenure, job separation costs should be larger for older workers with greater tenure. If the last of Fallick's reasons, seniority, exhibits an effect on pay independent of worker productivity, it could be considered with in the delayed compensation model advanced by Lazear.

Since the specific human capital, job matching and delayed compensation models all predict the cost of job separation to increase with tenure, it is difficult to distinguish between them on this basis and with our data we are unable to do so. We simply note that finding evidence of this relationship is consistent with the delayed compensation model but also with other theories. We also expect measures of general human capital, such as years of education, to maintain their value in re-employment.

A method allowing the specific human capital model to be distinguished from the delayed compensation model when the age of mandatory retirement varies was devised by Clark and Ogawa [1992]. In the years 1981 and 1986, the age of mandatory retirement in Japan varied by industry and firm size with larger firms tending to have higher ages of mandatory retirement and greater employee tenure. Mandatory retirement is explained in the delayed compensation model as a device to protect the firm from workers collecting their overpayment beyond the anticipated date of retirement. Clark and Ogawa found that a higher age of mandatory retirement reduced the slope of the earnings profile, which is consistent with the delayed payment model. They argue that this result shows that the specific human capital model is not the explanation for the steep earnings-experience profiles in Japan. They also find that workers of mandatory retirement age who choose to be rehired 
under a new contract at the same firm typically receive lower wages. This result also favors the delayed payment model over the specific human capital model. Pay follows productivity in the specific human capital model and the model provides no reason for pay to drop markedly on the date of mandatory retirement.

\section{Data}

A firm engaged in job placement services in Japan provided the data set. During the period covered, January 2000 and May 2003, the firm had served over one thousand job seekers. The data set contains information on 622 successfully placed workers initially employed in sixty-five generally large firms and going to 525 new, generally smaller firms. ${ }^{11}$ Workers excluded from the data set include those who fell out of contact with the placement firm, found new employment on their own, began their own business, had quit looking for work or were continuing clients still looking for work. ${ }^{12}$ The placement firm contracts only with the downsizing firm; there are no contracts with independent job seekers. The firm reports that it successfully places about $85 \%$ of its job seekers. Middle-aged workers are more likely to receive placement services and, the older a worker is, the longer is the period of search.

\footnotetext{
${ }^{11}$ The average employment level in the sixty-five initial firms was over 3500 . Since larger firms displaced more workers, the average worker originated in a firm of over 7500 . Though some of the new firms were large, the average worker was employed in a new firm with fewer than 1000 employees.

${ }^{12}$ The tables and regressions also exclude one individual with a drop in earnings between jobs of $\$ 650,000$, the regressions additionally exclude workers over 59 .
} 
Job seekers typically receive one job offer through the placement company after an average wait of about four months. Job seekers rarely pass up this offer but, when they do so, it is most commonly because they cannot accept the culture of the new firm.

The data provided by the placement firm includes earnings before and after displacement, age, gender, years of education, college major, hierarchical position of the initial job, certifications, occupation, and characteristics of the initial firm and of the new firm. The data set does not contain direct information on job tenure with the initial firm. Because tenure is a variable of particular interest, we impute tenure using national Japanese statistics. ${ }^{13}$

\footnotetext{
${ }^{13}$ To impute tenure we first categorized workers in our data by the categories used in the "Basic Survey on Wage Structure" collected by the Japanese Ministry of Health, Labour and Welfare. The Basic Survey categories included year (2000, 2001 and 2002), industry (all, manufacturing, communication and transport, wholesale and retail trade, financial and insurance, and service), age (all, 17 and under, 18-19, 20-24, 25-29, 30-34, 35-39, 40-44, 45-49, 50-54, 55-59, 60-64, 65 and above), firm size (all, 10-99 employees, 100-999 employees, 1000+ employees), education level (all, junior high school graduate, senior high school graduate, junior college/vocational school graduate, university graduates), and gender (all, male, female). The mapping from the placement data to the categories in the Basic Survey was straightforward but a few things should be noted. In cases where a missing value in the placement data prevented the assignment to a category, we used the data listed under "all" in the Basic Survey. The placement data runs through 2003 while the Basic Survey extends only to 2002. We applied the 2002 Basic Survey data to our placement data for both the years 2002 and 2003. We categorized the firms in the placement data listed as "systems/software," "professional" and "security" in the "services" industry in the Basic Survey. Firms listed as "stock" were assigned to the "financial and insurance" industry in the Basic Survey. We then applied the ratio of mean tenure to mean age that existed in each year, industry, age category, firm size, education
} 
Tables 1 though 4 provide descriptive statistics for the data set. Table 1 compares our data set with Japanese national averages in terms of education, earnings and industry representation. Table 2 lists the breakdown by the position in hierarchy, firm size, and industry in the initial firm and new firm. Table 3 lists educational characteristics, unemployment duration and wage changes by age category. Table 4 describes characteristics of the initial and new firms.

Table 1 shows the differences between the sample analyzed in this paper (labeled "Displacement Data") and national summary statistics from a survey of educational attainment of the adult population collected by the OECD in regards to education, a survey of 33,000 establishments conducted by the Japanese Ministry of Health, Labour and Welfare in regards to earnings and from a survey of the labour force conducted by the Statistics Bureau, MPHPT (now known as MIT) in regards to industry. It is evident that our sample is more educated than the general Japanese population. The table also shows that Japanese workers of all age categories, except ages 20-24, 30-34 and 50-54, had a slight increase in their earnings from 2000 to 2002. However, our sample shows large declines in earnings after being displaced from the initial firm for all age categories, except ages 30-34. Focusing on a comparison of mean earnings in US dollars across age groups in Japan and the mean earnings for the same age groups in our data before and after displacement, we find most of the workers in our data made above average earnings before displacement and below average earnings after displacement. level and gender cell in the Basic Survey to the age of the individual in the placement data to impute estimated tenure. 
Finally, table 1 shows that industry changes in our sample are similar to the changes taking place overall in the Japanese workforce. The movement out of the manufacturing, wholesale and retail trade, and finance, insurance and real estate industries to the service industry that occurred nationally is also reflected in the industry changes occurring in our data. Not surprisingly, for the displaced workers the industry shifts are more pronounced than for all workers. Nearly two-thirds of the workers in our sample lost jobs in manufacturing, reflecting the $5.8 \%$ decline nationally in manufacturing's share of total employment between 2000 and 2002. The industry to expand most strongly in the wake of the economic changes taking place was the service industry. Employment in the services industry increased from $4.6 \%$ to $26 \%$. The "other" industry category consists of the electronics, communications, and information technology industries.

Table 2 describes workers according to hierarchical position and firm size in both the initial firm and the new firm. Job changers generally moved to higher positions in their new jobs. This is primarily a move out of the lowest classification and into the next two higher positions, as well as a move from kacho (section chief) to bucho (department manager). However, we can also see that the displaced workers are being re-employed at smaller firms, which may account for their higher level upon re-employment. Employment in firms with fewer than 1000 employees rose from $32.5 \%$ to $82 \%$ as the result of job placement for workers in this sample.

Table 3 summarizes characteristics of the displaced workers by age. Unemployment duration, which is four months on average, rises with age. The marginal effect of being an extra year older is about two additional days 
of unemployment. The variable "Level" is such that the lowest level, noncorporate positions is assigned a value of one and the highest level, president is assigned a value of 8 . The oldest displaced workers, those over 55, experience the largest losses in earnings as a result of displacement. Similarly, while the average loss in earnings across the sample is $25.7 \%$, the earnings loss for workers over 40 is significantly greater than for those under 40 . Workers in their early 30s actually have a slight increase in income. Last, it appears in table 3 that changing industry is positively correlated with the income loss due to job displacement. This relationship is explored in estimations in the next section.

The results in table 3 contrast with those of Abe et al. in regards to the magnitude of job displacement costs. They found that displacement had no mean impact on the wages of those under 50 and only a $10-15 \%$ reduction for those over 55. The contrast with Abe et al. suggests that the impact of job separation on wages has risen perhaps because of the slower economic growth during the sample period. The size of the displacement costs must be interpreted with caution however because of the special nature of the sample. There are two primary reasons for this. First, the workers were displaced from high paying, large firms. Second, the workers were of higher income in their initial firms than if they were paid according to national averages given their industry, age, firm size, education and gender categories (this is discussed in the next section).

Even assuming that the results are only applicable to workers being displaced from primary sector firms, possible selection bias must taken in account. There are two possible sources of selection bias that might inflate 
the estimated displacement costs. First, if the workers considered the least able to find re-employment on their own are provided placement services, displacement costs will be larger. Second, to the extent that some workers find well-paid jobs on their own and do not appear in the placement data, displacement costs will be larger.

There are also two possible sources of selection bias that might reduce the estimated displacement costs. First, the provision of job placement services was to the advantage of the workers in the sample. Second, though some workers might find well-paid jobs on their own and not appear in the placement data, others not appearing in the placement data are those who quit looking for work, were still looking for work or were unable to find jobs even with the help of placement services. Unfortunately, no conclusive statement can be made about whether the overall influence of selection bias causes an over or underestimate of job displacement costs for workers in the primary sector. While selection bias may be altering overall job displacement costs, it is less obvious that it is causing the job displacement costs to rise so strongly with age.

Table 4 summarizes firm characteristics of the initial and new firm by worker age cohort. It is evident that workers in all age categories are going to smaller firms upon re-employment and firms displacing workers have negative profits that average sixty million dollars. This suggests that displacements were financially motivated. Younger displaced workers come disproportionately from manufacturing. In this data set, over $90 \%$ of those displaced workers under the age of 34 come from manufacturing. Due to missing data for the new firms, we have few observations for these characteristics. 


\section{Estimation of Job Displacement Penalties}

The analysis of job displacement penalties takes place in three parts. First, we present the estimated age-earnings and tenure-earnings profiles in order to provide a sense of the large magnitude of the job separation penalties in these data. Second, separate estimates of the earnings equations for the initial firm and the new firm are presented. Third, the change in earnings between the initial job and the new job is analyzed.

\subsection{Earnings Profiles}

Figure 1 shows the extent to which age is more highly rewarded in initial employment than in new employment in the Japanese labor market and the cost of job separation for older workers. ${ }^{14}$ In addition to providing the ageearnings profiles for workers in their initial job (Firm 1) and new job (Firm 2 ), we have included an age-earnings profile that displays what workers in the sample would earn if they were paid according to national averages. ${ }^{15}$

\footnotetext{
${ }^{14}$ The age-earnings profiles depicted are generated from the following regression estimates: Income1 = -82,682 + 5,986.91 Age - 56.79 Age $^{2}$ with t-statistics 5.7 and -4.6 for Age and $\mathrm{Age}^{2}, \mathrm{~N}=377$ and R-square $=0.24 ;$ Income2 $=-90,587+6,690.11$ Age -75.95 $\mathrm{Age}^{2}$ with t-statistics 8.3 and -8.1 for Age and $\mathrm{Age}^{2}, \mathrm{~N}=509$ and R-square = 0.13; Imputed Income $=-49318+4064.47$ Age -38.94 Age $^{2}$ with t-statistics 11.5 and -9.5 for Age and $\mathrm{Age}^{2}, \mathrm{~N}=609$ and R-square $=0.41$.

${ }^{15}$ In the same way we imputed tenure, we impute income at national averages. Workers in our data are grouped by the categories used in the "Basic Survey on Wage Structure" collected by the Japanese Ministry of Health, Labour and Welfare. The Basic Survey categories included year, industry, age, firm size, education level and gender. After mapping from the placement data to the categories in the Basic Survey, we applied the ratio of
} 
This profile is included for comparison purposes. Workers in their initial jobs in the sample are more highly paid and on a steeper pay profile than if paid according to the national averages given their industry, age, firm size, education and gender. This may contribute to the large cost of job loss for these workers. Figure 2 shows the tenure-earnings profiles of the workers in initial and new employment and displays the extent to which job separation costs rise with tenure. ${ }^{16}$

These figures can be interpreted in light of Lazear's model of delayed compensation. The implications that older workers, with more years of firm tenure, should experience larger reductions in pay as a result of involuntary job separations are born out in the figures. The figures clearly display older, more tenured workers losing more income upon job change. We note that the loss of specific human capital or the loss of a superior job match upon involuntary job separation also imply job displacement penalties that increase with age and tenure.

Figure 3 depicts the total loss in earnings suffered by displaced workers assuming retirement at age sixty and that the difference between the worker's earnings and what the worker would have earned had separation not occurred remains constant in real terms and is reflected by the change in earnings mean contractual cash earnings to mean age that existed in each year, industry, age, firm size, education and gender cell in the Basic Survey to the age of the individual in the placement data to arrive at imputed income.

${ }^{16}$ The tenure-earnings profiles depicted are generated from the following regression estimates: Income $1=20,301+4,381.48$ Tenure - 82.21 Tenure $^{2}$ with t-statistics 5.4 and -3.0 for Tenure and Tenure ${ }^{2}, \mathrm{~N}=377$ and R-square $=0.25 ;$ Income $2=25,163+3,069.67$ Tenure - 82.48 Tenure $^{2}$ with t-statistics 4.9 and -4.0 for Tenure and Tenure ${ }^{2}, \mathrm{~N}=509$ and R-square $=0.07$. 
between initial and new employment. The total cumulative loss in earnings for each age category is generated by summing the immediate loss for each age cohort from the median age of the cohort to age sixty. The immediate earnings loss from job separation for each five-year age cohort is presented in column 9 of table 6 . It provides evidence of larger displacement costs for older workers, though the relationship does not appear to be smooth like those depicted in figures 1 and 2. Though the immediate loss in earnings in greatest for older workers, if projected out in the simple way we have, workers in their forties suffer the largest aggregate losses until retirement.

\subsection{Earnings Equations}

The first model specification investigated is a regression model in which income at the initial firm and in the new firm is tied to age, estimated tenure and other individual characteristics. The estimations treat the data as two cross sections, first considering worker income in the initial job and then in the new job. Years of education and level in the initial firm's hierarchy cause a large number of observations to be lost so these are not entered into all of the regressions reported. Tenure is also not entered into all regressions because it is imputed. ${ }^{17}$ We estimate these models to determine the difference in the value placed on worker characteristics between the initial firm and the new firm. Human capital theory suggests that general training in the form of years of education should be valued in both jobs. Estimated tenure should have reduced value in subsequent employment according to

\footnotetext{
${ }^{17}$ The coefficent on tenure may be biased towards zero due to measurement error and the standard errors invalid.
} 
the delayed compensation model and both the specific human capital and job matching theories. The model is specified as follows:

$$
\ln I_{i j}=Z_{i} \gamma+\varepsilon_{i j}
$$

where

- $\ln I_{i j}$ is the logarithm of income of individual $i$ at firm $j$ measured in real 2000 US dollars (deflated annually and converted at a constant exchange rate of 107.1 yen to the dollar).

- $Z_{i}$ is a vector of individual specific attributes (age, age ${ }^{2}$, gender, education, imputed tenure and initial hierarchical level.

- $\varepsilon_{i j}$ is a random shock (iid) with a mean of zero.

Two panels of regression results are presented in table $5 .{ }^{18}$ The dependent variable in the first panel is log income at the initial firm. The dependent variable in the second panel is log income at the new firm. Age is valued in both initial and subsequent employment. The negative sign on age-squared gives the earnings profiles the familiar concave shape. Age and age squared alone explain one third of the variation in log income at the initial firm but only half as much at the new firm. Comparing column 1 in each of the log income panels of table 5, the marginal effect on earnings of aging one year for

\footnotetext{
${ }^{18}$ Table 7 contains a model including firm effects and the same variable specifications as in table 5. The same basic results are found. Excluding from the sample those over age 55 , under the presumption that they are simply being retired, resulted in very minimal changes to signs or significance of the estimated parameters. The monthly unemployment rate was never statistically significant and specifications including it are not presented.
} 
a 40 year old is a positive $2.6 \%$ in initial firms and $1.4 \%$ in new firms. The extent to which older workers are burdened with greater job displacement costs is more clearly displayed in tables 6 and 8 .

Firm effects (for the initial firm) are included in table 7 and the estimation results display in the same pattern in regards to age as table 5. This estimation controls for unobserved heterogeneity between initial firms. While we can't control for unobserved individual heterogeneity, controlling for firm effects serves this purpose to some extent. The average initial firm is displacing roughly ten employees and these workers presumably share some of the same characteristics and circumstances.

The premium the displaced workers receive for years of education increases slightly in the post-displacement firm. Column 3 in the first two panels of table 5 shows the premium for an additional year of education to be about $1.9 \%$ in initial employment and $3.7 \%$ in new employment. This finding offers some support for the finding of Podgursky and Swaim [1987] that higher levels of education reduce earnings losses. However, the analysis of income change in table 6 shows the effect of education to be positive but statistically insignificant. Some of the difficulty in achieving statistically significant results for education may be due to the reduction in sample size caused by missing values.

Tenure has a positive and significant effect on income in the initial job but is smaller and less significant in subsequent employment. This corresponds to the finding in the literature that tenure in the initial firm falls in value in the new firm. The same finding are evident in table 7 in which initial firm effects are included. While these findings are in accord with theory, in table 
6 we see that tenure in the initial firm increases job displacement costs but the estimate is not statistically significant (though close in the model with firm effects in table 8) after already controlling for age. Initial hierarchical level pays larger returns at the new firm, estimates at the initial firm are insignificant. In explaining the change in income, level in the initial firm's hierarchy is not significant.

\subsection{Displacement Costs}

The second model specification investigated is a regression model in which the change income between the initial firm and the new firm is tied to age and other individual and firm characteristics. The estimations treat the data as a single cross section. The model is specified as follows:

$$
\Delta I_{i j, k}=Z_{i} \gamma+\varepsilon_{i j}
$$

where

- $\Delta I_{i j, k}=I_{i j}-I_{i k}$ is the change in the income of individual $i$ between the initial firm $j$ and the new firm $k$ measured in real U.S. dollars.

- $Z_{i}$ is a vector of individual specific attributes (age, gender, education, tenure, total employment in the initial firm, initial hierarchical level, days of unemployment, binary change of industry indicator, and binary occupation, certification and major indicators).

- $\varepsilon_{i j}$ is a random shock (iid) with a mean of zero. 
Table 6 examines the change in income brought about by job separation. In the first column of table 6 , we see that workers lose about $\$ 1,100$ for every additional year of age when involuntarily changing jobs. A gender effect appeared in the level estimates in table 5. Females, in initial employment and new employment, earned less than men when controls for education and level were omitted. However, gender has a statistically insignificant effect on the change in earnings. The size of the initial firm is also not influential. Longer spells of unemployment appear to increase the cost of job separation by about $\$ 45$ a day when the term is treated as exogenous. This is not an inconsequential amount because our average worker is in job search for about three months. Column 8 of table 6 shows that when treating the length of the unemployment spell as endogenous and instrumenting it, it becomes statistically insignificant.

Changing industries carries a high wage penalty, workers switching industries lose about $\$ 5,000$ ( $\$ 4000$ in a model with firm effects) when industry change is treated exogenously. This suggests that the labor market values the experience workers gain in a particular industry and the workers suffer when they cannot apply that industry training in new employment. The changing distribution of employment in Japan away from manufacturing and into the service industry caused workers in manufacturing to lose disproportionately more jobs and forced many of these workers to find work in different industries. About two-thirds of the workers in our sample changed industries upon gaining new employment. Treating industry change as endogenous and instrumenting it with the monthly unemployment at the start of the workers spell of unemployment and imputed tenure does not reduce its impact as in 
the case of the spell of unemployment.

\section{Conclusion}

At a time when Japan was undergoing a transition to a less manufacturing based economy and suffering from economic stagnation, this study estimated the job loss penalties associated with involuntary job separation. Our primary finding is that the income premium for each year of age, while positive in post-displacement employment, is about $\$ 1,100$ less than the income premium received in initial employment. Therefore, we find that the older the worker, the greater the loss in annual income due to involuntary job loss. The findings regarding the job loss penalty are consistent with the delayed compensation model, the job matching model and the model of specific human capital. It should be noted that the large job displacement costs found in this study came from a sample that was employed initially at large firms and was paid higher than the national averages for their industry, age, firm size, education and gender. Additionally, selection bias might have to some extent increased job displacement costs.

The decline of the manufacturing sector in Japan caused many workers to find employment in other industries. Changing industry increased job displacement penalties markedly and we speculated that this was due to the loss of industry specific capital. Additionally, we have found that years of education continue to be highly valued throughout a worker's career and may have a larger effect on subsequent earnings. Thus, general training might help to mitigate the losses caused by involuntary displacement. 


\section{References}

[1] Abe, M., Higuchi, Y., Nakamura, M., Kuhn, P. and Sweetman, A., 2002. "Worker Displacement in Japan and Canada." In: Kuhn, P. J. (Ed.), Losing Work, Moving On: International Perspectives on Worker Displacement, Chapter 3. Upjohn Institute for Employment Research.

[2] Clark, R. L. and Ogawa, N., 1992. "The Effect of Mandatory Retirement on Earnings Profiles in Japan," Ind. Lab. Relat. Rev. 45:2, 258-266.

[3] Fallick, B. C., 1996. "A Review of the Recent Empirical Literature on Displaced Workers," Ind. Lab. Relat. Rev. 50:1, 5-16.

[4] Farber, H. S., Hall, R. and Pencavel, J., 1993. "The Incidence and Costs of Job Loss: 1982-91," Brookings Pap. Econ. Act. Microeconomics, 1, 73-132.

[5] Fujiki, H., Nakada, S. K. and Tachibanaki, T., 2001. "Structural Issues in the Japanese Labor Market: An Era of Variety, Equity, and Efficiency or an Era of Bipolarization?" Monetary Econ. Studies (Special Edition) February, 177- 211.

[6] Genda, G. and Rebick, M., 2000. "Japanese Labour in the 1990s: Stability and Stagnation," Oxford Rev. of Econ. Policy, 16:2, 85-102.

[7] Gibbons, R. and Katz, L. F., 1991. "Layoffs and Lemons," J. Lab. Econ. 9:4, 351-380.

[8] Hamermesh, D. S., 1989. "What Do We Know About Worker Displacement in the U.S.?" Ind. Relat. 27, 51-59. 
[9] Hashimoto, M. and Raisian, J., 1985. "Employment Tenure and Earnings Profiles in Japan and the United States," Amer. Econ. Rev. 75:4, 721-735.

[10] Hutchens, R. M., 1987. "A Test of Lazear's Theory of Delayed Payment Contracts," J. Lab. Econ. 5:4, Part 2: The New Economics of Personnel, S153-S170.

[11] Jacobson, L., LaLonde, R. and Sullivan, D., 1993. "Earnings Losses of Displaced Workers," Amer. Econ. Rev. 83:4, 685-709.

[12] Kato, T., 2001. "The End of Lifetime Employment in Japan?: Evidence from National Surveys and Field Research," J. Japanese Intl. Economies. 15:4, 489-514.

[13] Kuhn, P. J., 2003. "Summary and Synthesis," In: Kuhn, P. J. (Ed.), Losing Work, Moving On: International Perspectives on Worker Displacement, Chapter 1. Upjohn Institute for Employment Research.

[14] Lazear, E., 1979. "Why is There Mandatory Retirement?" J. Polit. Economy. 6, 1261-1284.

[15] Nakagawa, T., Nishizaki, K. and Kamiya, T., 2002. "Workers face the need to swallow their market prices," The Asahi Shimbun, (IHT/Asahi). July 30 .

[16] Pesek Jr., W., 2003. “'Suicide Economy' Killing More Japanese," Bloomberg News. March 11. 
[17] Podgursky, M. and Swaim, P., 1987. "Job Displacement and Earnings Loss: Evidence from the Displaced Worker Survey," Ind. Lab. Relat. Rev. 41:1, 17-29.

[18] Ruhm, C. J., 1987. "The Economic Consequences of Labor Mobility," Ind. Lab. Relat. Rev. 41:1, 30-42.

[19] Ruhm, C. J., 1991. "Displacement Induced Joblessness," Rev. Econ. Statist. 73:3, 517- 522 .

[20] Topel, R., 1993. "What Have We Learned from Empirical Studies of Unemployment and Turnover?" Amer. Econ. Rev. 83:2, Papers and Proceedings of the Hundred and Fifth Annual Meeting of the American Economic Association, 110-115. 
Table 1

Comparison between Displacement Dataset and National Data

\begin{tabular}{|c|c|c|c|c|c|c|c|}
\hline & \multicolumn{3}{|c|}{ Displacement Data } & \multicolumn{4}{|c|}{ National Averages } \\
\hline Education $^{1}$ & \multicolumn{3}{|c|}{$2000-2002$} & & \multicolumn{3}{|c|}{2002} \\
\hline Jr High School & \multicolumn{3}{|c|}{$7.2 \%$} & & \multicolumn{3}{|c|}{$16.3 \%$} \\
\hline Sr High School & \multicolumn{3}{|c|}{31.4} & & \multicolumn{3}{|c|}{47.4} \\
\hline Jr College or Vocational school & \multicolumn{3}{|c|}{9.0} & & \multicolumn{3}{|c|}{16.0} \\
\hline University or more & \multicolumn{3}{|c|}{52.5} & & \multicolumn{3}{|c|}{20.0} \\
\hline Earnings ${ }^{2}$ & Firm 1 & Firm 2 & $\begin{array}{l}\text { \% chg } \\
\text { between } \\
\text { firms }\end{array}$ & 2000 & 2001 & 2002 & $\begin{array}{c}\% \text { chg } \\
\text { from } 2000 \\
\text { to } 2002\end{array}$ \\
\hline \multicolumn{8}{|l|}{ Ages } \\
\hline 20-59 & 66,088 & 50,430 & -23.7 & & & & \\
\hline $20-24$ & 30,419 & 26,760 & -12.0 & 28,406 & 28,350 & 28,338 & -0.2 \\
\hline $25-29$ & 35,617 & 33,408 & -6.2 & 36,116 & 36,384 & 36,171 & 0.2 \\
\hline $30-34$ & 42,113 & 42,272 & 0.4 & 44,533 & 44,822 & 44,125 & -0.9 \\
\hline $35-39$ & 63,369 & 53,992 & -14.8 & 51,462 & 52,160 & 51,674 & 0.4 \\
\hline $40-44$ & 68,302 & 54,080 & -20.8 & 54,721 & 55,580 & 55,447 & 1.3 \\
\hline $45-49$ & 74,247 & 56,858 & -23.4 & 56,292 & 57,279 & 57,076 & 1.4 \\
\hline $50-54$ & 74,391 & 53,174 & -28.5 & 57,821 & 58,164 & 57,161 & -1.1 \\
\hline $55-59$ & 74,446 & 43,217 & -41.9 & 53,389 & 54,680 & 54,224 & 1.6 \\
\hline $60-64$ & 93,840 & 56,304 & -40.0 & 37,434 & 39,712 & 38,847 & 3.8 \\
\hline Industry $^{3}$ & Firm 1 & Firm 2 & $\begin{array}{l}\text { \% chg } \\
\text { between } \\
\text { firms }\end{array}$ & 2000 & 2001 & 2002 & $\begin{array}{c}\text { \% chg } \\
\text { from } 2000 \\
\text { to } 2002\end{array}$ \\
\hline Manufacturing & $64.1 \%$ & $32.4 \%$ & $-49.5 \%$ & $20.5 \%$ & $20.0 \%$ & $19.3 \%$ & $-5.9 \%$ \\
\hline Electricity, gas, heat and water supply & 0.0 & 1.2 & & 0.5 & 0.5 & 0.5 & 1.8 \\
\hline Transport and communications & 1.3 & 7.0 & 434.6 & 6.4 & 6.3 & 6.3 & -1.4 \\
\hline Wholesale and retail trade & 19.2 & 11.6 & -39.6 & 22.9 & 23.0 & 22.7 & -0.7 \\
\hline Finance, insurance and real estate & 9.8 & 7.8 & -20.8 & 3.8 & 3.7 & 3.8 & -1.0 \\
\hline Services & 4.6 & 26.0 & 468.5 & 26.7 & 27.6 & 28.5 & 6.9 \\
\hline Other & 1.0 & 14.1 & 0.0 & 19.2 & 18.9 & 18.8 & -2.0 \\
\hline
\end{tabular}

Notes:

1. Education data for Japan was obtained through the OECD (http://www.oecd.org/dataoecd/52/38/33669031.xls).

The following statistics for Japan were used to match with our data:

Jr High School = Below Upper Secondary

Sr High School = Upper Secondary

Jr College or Vocational school $=$ Tertiary Type B institutions

University or more $=$ Tertiary Type A institutions

2. Earnings data for Japan was obtained from the Japan Basic Survey on Wage Structure (http://www.mhlw.go.jp).

3. Industry data for Japan was obtained through the Statistics Bureau, MPHPT (http://www.stat.go.jp). 
Table 2

Change in Hierarchical Level and Firm Size from Job Separation

\begin{tabular}{|c|c|c|c|c|}
\hline & \multicolumn{4}{|c|}{ Percentage of Workers } \\
\hline & Before Separation & $\mathbf{N}$ & After Separation & $\mathbf{N}$ \\
\hline Average Level & $3.1 \%$ & $(206)$ & $3.4 \%$ & $(204)$ \\
\hline Stacho (president, 8) & $0.0 \%$ & $(0)$ & $0.5 \%$ & (1) \\
\hline Bucho (department manager, 7) & $2.4 \%$ & (5) & $10.3 \%$ & $(21)$ \\
\hline Kacho (section chief, 6) & $17.0 \%$ & (35) & $8.8 \%$ & (18) \\
\hline Kakaricho (chief clerk, 5) & $2.9 \%$ & $(6)$ & $3.4 \%$ & $(7)$ \\
\hline Jicho (vice chief, 4) & $23.8 \%$ & (49) & $21.1 \%$ & (43) \\
\hline Supervisory duties (3) & $9.2 \%$ & (19) & $17.2 \%$ & (35) \\
\hline No supervisory duties (2) & $6.3 \%$ & (13) & $18.6 \%$ & (38) \\
\hline Non-corporate position (1) & $38.3 \%$ & (79) & $20.1 \%$ & $(41)$ \\
\hline Large firm (>10,000 ee) & $35.7 \%$ & $(198)$ & $0.8 \%$ & $(2)$ \\
\hline $\begin{array}{l}\text { Medium firm (>1,000 ee, } \\
<10,000 \text { ee) }\end{array}$ & $31.8 \%$ & $(176)$ & $17.2 \%$ & $(45)$ \\
\hline Small firm (<1,000 ee $)$ & $32.5 \%$ & (180) & $82.0 \%$ & (214) \\
\hline
\end{tabular}


Table 3

Worker Characteristics and Job Separation Outcomes by Age

\begin{tabular}{|c|c|c|c|c|c|c|c|c|c|c|c|c|c|c|}
\hline Ages & $\begin{array}{c}\text { Total } \\
\text { Number } \\
\text { of } \\
\text { workers }\end{array}$ & Male & $\begin{array}{l}\text { University } \\
\text { Graduate }\end{array}$ & $\begin{array}{l}\text { Engineering/ } \\
\text { Math Major }\end{array}$ & $\begin{array}{c}\text { Business/ } \\
\text { Law } \\
\text { Major } \\
\end{array}$ & $\begin{array}{l}\text { Other } \\
\text { Major }\end{array}$ & $\begin{array}{c}\text { Average } \\
\text { Duration of } \\
\text { Unemployment }\end{array}$ & $\begin{array}{c}\text { Average } \\
\text { Level } \\
\text { Firm } 1 \\
\end{array}$ & $\begin{array}{c}\text { Average } \\
\text { Level } \\
\text { Firm 2 } \\
\end{array}$ & $\begin{array}{l}\text { Pct Level } \\
\text { Increase }\end{array}$ & $\begin{array}{c}\text { Pct } \\
\text { Industry } \\
\text { Change } \\
\end{array}$ & $\begin{array}{l}\text { Average } \\
\text { Income } \\
\text { Firm 1 } \\
\end{array}$ & $\begin{array}{l}\text { Average } \\
\text { Income } \\
\text { Firm2 } \\
\end{array}$ & $\begin{array}{c}\text { Pct } \\
\text { Change } \\
\text { in } \\
\text { Income }\end{array}$ \\
\hline 20-68 & 621 & $\begin{array}{l}89.9 \% \\
(551)\end{array}$ & $\begin{array}{c}52.5 \% \\
(117)\end{array}$ & $\begin{array}{c}35.0 \% \\
(41)\end{array}$ & $\begin{array}{c}54.7 \% \\
(64)\end{array}$ & $\begin{array}{c}10.3 \% \\
(12)\end{array}$ & $\begin{array}{c}120 \\
(618)\end{array}$ & $\begin{array}{c}3.1 \\
(206)\end{array}$ & $\begin{array}{c}3.4 \\
(204)\end{array}$ & $\begin{array}{l}23.0 \% \\
(143)\end{array}$ & $\begin{array}{l}66.2 \% \\
(412)\end{array}$ & $\begin{array}{c}67,774 \\
(379)\end{array}$ & $\begin{array}{c}50,357 \\
(513)\end{array}$ & $-25.7 \%$ \\
\hline $20-29$ & 43 & $\begin{array}{l}77.5 \% \\
(31)\end{array}$ & $\begin{array}{c}58.8 \% \\
(10)\end{array}$ & $\begin{array}{c}40.0 \% \\
(4)\end{array}$ & $\begin{array}{c}60.0 \% \\
(6)\end{array}$ & $\begin{array}{l}0.0 \% \\
(0)\end{array}$ & $\begin{array}{c}70 \\
(43)\end{array}$ & $\begin{array}{r}3.4 \\
(15)\end{array}$ & $\begin{array}{l}2.4 \\
(10)\end{array}$ & $\begin{array}{c}14.0 \% \\
(6)\end{array}$ & $\begin{array}{c}72.1 \% \\
(31)\end{array}$ & $\begin{array}{c}34,429 \\
(35)\end{array}$ & $\begin{array}{c}32,330 \\
(37)\end{array}$ & $-6.1 \%$ \\
\hline $30-34$ & 40 & $\begin{array}{c}80.0 \% \\
(32)\end{array}$ & $\begin{array}{c}62.5 \% \\
(10)\end{array}$ & $\begin{array}{l}30.0 \% \\
\text { (3) }\end{array}$ & $\begin{array}{l}50.0 \% \\
(5)\end{array}$ & $\begin{array}{l}20.0 \% \\
(2)\end{array}$ & $\begin{array}{l}97 \\
(40)\end{array}$ & $\begin{array}{r}2.1 \\
(17)\end{array}$ & $\begin{array}{l}2.6 \\
(8)\end{array}$ & $\begin{array}{c}17.5 \% \\
(7)\end{array}$ & $\begin{array}{c}40.0 \% \\
(16)\end{array}$ & $\begin{array}{c}42,113 \\
(20)\end{array}$ & $\begin{array}{c}42,272 \\
(29)\end{array}$ & $0.4 \%$ \\
\hline 35-39 & 89 & $\begin{array}{l}85.2 \% \\
(75)\end{array}$ & $\begin{array}{c}72.4 \% \\
(21)\end{array}$ & $\begin{array}{c}45.0 \% \\
(9)\end{array}$ & $\begin{array}{c}50.0 \% \\
(10)\end{array}$ & $\begin{array}{l}5.0 \% \\
(1)\end{array}$ & $\begin{array}{l}102 \\
(89)\end{array}$ & $\begin{array}{r}3.6 \\
(25)\end{array}$ & $\begin{array}{l}3.9 \\
(21)\end{array}$ & $\begin{array}{c}16.9 \% \\
(15)\end{array}$ & $\begin{array}{c}49.4 \% \\
(44)\end{array}$ & $\begin{array}{c}63,369 \\
(73)\end{array}$ & $\begin{array}{c}53,992 \\
(75)\end{array}$ & $-14.8 \%$ \\
\hline $40-44$ & 91 & $\begin{array}{l}93.3 \% \\
(84)\end{array}$ & $\begin{array}{c}65.0 \% \\
(13)\end{array}$ & $\begin{array}{l}41.7 \% \\
(5)\end{array}$ & $\begin{array}{l}41.7 \% \\
(5)\end{array}$ & $\begin{array}{l}16.7 \% \\
(2)\end{array}$ & $\begin{array}{l}117 \\
(91)\end{array}$ & $\begin{array}{r}3.7 \\
(18)\end{array}$ & $\begin{array}{l}3.8 \\
(24)\end{array}$ & $\begin{array}{c}20.9 \% \\
(19)\end{array}$ & $\begin{array}{c}78.0 \% \\
(71)\end{array}$ & $\begin{array}{c}80,784 \\
(51)\end{array}$ & $\begin{array}{c}53,989 \\
(71)\end{array}$ & $-33.2 \%$ \\
\hline $45-49$ & 105 & $\begin{array}{c}91.3 \% \\
(95)\end{array}$ & $\begin{array}{c}44.2 \% \\
(19)\end{array}$ & $\begin{array}{c}20.0 \% \\
(4)\end{array}$ & $\begin{array}{c}70.0 \% \\
(14)\end{array}$ & $\begin{array}{c}10.0 \% \\
(2)\end{array}$ & $\begin{array}{c}118 \\
(103)\end{array}$ & $\begin{array}{r}2.4 \\
(38)\end{array}$ & $\begin{array}{c}3.8 \\
(42)\end{array}$ & $\begin{array}{c}29.5 \% \\
(31)\end{array}$ & $\begin{array}{c}67.6 \% \\
(71)\end{array}$ & $\begin{array}{c}74,247 \\
(55)\end{array}$ & $\begin{array}{c}56,858 \\
(86)\end{array}$ & $-23.4 \%$ \\
\hline 50-54 & 156 & $\begin{array}{l}94.8 \% \\
(146)\end{array}$ & $\begin{array}{c}49.1 \% \\
(27)\end{array}$ & $\begin{array}{c}34.6 \% \\
(9)\end{array}$ & $\begin{array}{c}53.8 \% \\
(14)\end{array}$ & $\begin{array}{c}11.5 \% \\
\text { (3) }\end{array}$ & $\begin{array}{c}139 \\
(154)\end{array}$ & $\begin{array}{r}3.6 \\
(53)\end{array}$ & $\begin{array}{c}3.3 \\
(66)\end{array}$ & $\begin{array}{c}26.9 \% \\
(42)\end{array}$ & $\begin{array}{l}69.2 \% \\
(108)\end{array}$ & $\begin{array}{c}74,391 \\
(84)\end{array}$ & $\begin{array}{c}53,174 \\
(136)\end{array}$ & $-28.5 \%$ \\
\hline 55-59 & 94 & $\begin{array}{c}91.4 \% \\
(85)\end{array}$ & $\begin{array}{c}42.5 \% \\
(17)\end{array}$ & $\begin{array}{c}36.8 \% \\
(7)\end{array}$ & $\begin{array}{c}52.6 \% \\
(10)\end{array}$ & $\begin{array}{c}10.5 \% \\
(2)\end{array}$ & $\begin{array}{l}142 \\
(94)\end{array}$ & $\begin{array}{r}2.7 \\
(37)\end{array}$ & $\begin{array}{c}3.0 \\
(31)\end{array}$ & $\begin{array}{c}23.4 \% \\
(22)\end{array}$ & $\begin{array}{c}72.3 \% \\
(68)\end{array}$ & $\begin{array}{c}74,446 \\
(60)\end{array}$ & $\begin{array}{c}43,217 \\
(76)\end{array}$ & $-41.9 \%$ \\
\hline 60-68 & 3 & $\begin{array}{c}66.7 \% \\
(2)\end{array}$ & $\begin{array}{c}0.0 \% \\
(0)\end{array}$ & $\begin{array}{l}0.0 \% \\
(0)\end{array}$ & $\begin{array}{l}0.0 \% \\
(0)\end{array}$ & $\begin{array}{c}0.0 \% \\
(0)\end{array}$ & $\begin{array}{l}159 \\
(3)\end{array}$ & $\begin{array}{l}2.5 \\
(2)\end{array}$ & $\begin{array}{l}1.0 \\
(1)\end{array}$ & $\begin{array}{c}0.0 \% \\
(0)\end{array}$ & $\begin{array}{c}100.0 \% \\
\text { (3) }\end{array}$ & $\begin{array}{c}93,840 \\
(1)\end{array}$ & $\begin{array}{c}46,958 \\
(2)\end{array}$ & $-50.0 \%$ \\
\hline
\end{tabular}

Note: The number of observations is in parentheses. 
Table 4

Firm Characteristics by Worker Age

\begin{tabular}{|c|c|c|c|c|c|c|c|c|c|}
\hline \multirow[b]{3}{*}{ Ages } & \multicolumn{9}{|c|}{ Before Separation } \\
\hline & \multicolumn{4}{|c|}{ Firm } & \multicolumn{5}{|c|}{ Industry } \\
\hline & $\begin{array}{l}\text { Average } \\
\text { Number of } \\
\text { Workers }\end{array}$ & Average Sales & Average Profits & Average Assets & $\begin{array}{c}\text { Manufact- } \\
\text { uring }\end{array}$ & $\begin{array}{l}\text { Wholesale/ } \\
\text { Trade/ Retai] }\end{array}$ & $\begin{array}{l}\text { Bond/ } \\
\text { Financial }\end{array}$ & Services & Other \\
\hline $20-68$ & $\begin{array}{l}7,766 \\
(554)\end{array}$ & $\begin{array}{c}9,334,530,082 \\
(390)\end{array}$ & $\begin{array}{c}-63,379,682 \\
(384)\end{array}$ & $\begin{array}{c}10,644,224,828 \\
(331)\end{array}$ & $\begin{array}{c}64.1 \% \\
(393)\end{array}$ & $\begin{array}{l}19.2 \% \\
(118)\end{array}$ & $\begin{array}{c}9.8 \% \\
(60)\end{array}$ & $\begin{array}{c}4.6 \% \\
(28)\end{array}$ & $\begin{array}{l}2.3 \% \\
(14)\end{array}$ \\
\hline $20-29$ & $\begin{array}{c}11,419 \\
(41)\end{array}$ & $\begin{array}{c}12,033,786,661 \\
\text { (32) }\end{array}$ & $\begin{array}{c}-104,491,548 \\
(32)\end{array}$ & $\begin{array}{c}12,391,232,098 \\
(32)\end{array}$ & $\begin{array}{c}97.7 \% \\
(42)\end{array}$ & $\begin{array}{c}0.0 \% \\
(0)\end{array}$ & $\begin{array}{c}2.3 \% \\
(1)\end{array}$ & $\begin{array}{c}0.0 \% \\
(0)\end{array}$ & $\begin{array}{c}0.0 \% \\
(0)\end{array}$ \\
\hline $30-34$ & $\begin{array}{c}3,567 \\
(35)\end{array}$ & $\begin{array}{c}4,733,301,005 \\
(21)\end{array}$ & $\begin{array}{c}130,931,892 \\
(20)\end{array}$ & $\begin{array}{c}4,797,003,826 \\
(20)\end{array}$ & $\begin{array}{c}90.0 \% \\
(36)\end{array}$ & $\begin{array}{l}2.5 \% \\
(1)\end{array}$ & $\begin{array}{c}5.0 \% \\
(2)\end{array}$ & $\begin{array}{c}0.0 \% \\
(0)\end{array}$ & $\begin{array}{c}2.5 \% \\
(1)\end{array}$ \\
\hline $35-39$ & $\begin{array}{c}4,948 \\
(83)\end{array}$ & $\begin{array}{c}4,684,946,430 \\
(52)\end{array}$ & $\begin{array}{c}67,464,351 \\
(49)\end{array}$ & $\begin{array}{c}5,942,739,490 \\
(40)\end{array}$ & $\begin{array}{c}59.1 \% \\
(52)\end{array}$ & $\begin{array}{c}12.5 \% \\
(11)\end{array}$ & $\begin{array}{l}27.3 \% \\
(24)\end{array}$ & $\begin{array}{c}1.1 \% \\
(1)\end{array}$ & $\begin{array}{c}0.0 \% \\
(0)\end{array}$ \\
\hline $40-44$ & $\begin{array}{c}5,254 \\
(80)\end{array}$ & $\begin{array}{c}6,662,860,017 \\
(56)\end{array}$ & $\begin{array}{c}-3,619,945 \\
(55)\end{array}$ & $\begin{array}{c}7,893,780,804 \\
\text { (44) }\end{array}$ & $\begin{array}{l}57.8 \% \\
(52)\end{array}$ & $\begin{array}{c}20.0 \% \\
(18)\end{array}$ & $\begin{array}{c}7.8 \% \\
(7)\end{array}$ & $\begin{array}{l}10.0 \% \\
(9)\end{array}$ & $\begin{array}{c}4.4 \% \\
(4)\end{array}$ \\
\hline $45-49$ & $\begin{array}{c}8,017 \\
(94)\end{array}$ & $\begin{array}{c}10,425,651,218 \\
\text { (68) }\end{array}$ & $\begin{array}{c}-82,375,366 \\
(67)\end{array}$ & $\begin{array}{c}11,819,709,925 \\
\text { (55) }\end{array}$ & $\begin{array}{l}51.0 \% \\
(53)\end{array}$ & $\begin{array}{c}29.8 \% \\
(31)\end{array}$ & $\begin{array}{c}8.7 \% \\
(9)\end{array}$ & $\begin{array}{l}8.7 \% \\
(9)\end{array}$ & $\begin{array}{c}1.9 \% \\
(2)\end{array}$ \\
\hline $50-54$ & $\begin{array}{l}8,653 \\
(132)\end{array}$ & $\begin{array}{c}10,087,342,843 \\
(94)\end{array}$ & $\begin{array}{c}-81,573,538 \\
(94)\end{array}$ & $\begin{array}{c}12,397,878,012 \\
\text { (77) }\end{array}$ & $\begin{array}{c}53.6 \% \\
(81)\end{array}$ & $\begin{array}{c}31.1 \% \\
(47)\end{array}$ & $\begin{array}{c}8.6 \% \\
(13)\end{array}$ & $\begin{array}{c}4.0 \% \\
(6)\end{array}$ & $\begin{array}{c}2.6 \% \\
(4)\end{array}$ \\
\hline $55-59$ & $\begin{array}{c}11,382 \\
(85)\end{array}$ & $\begin{array}{c}13,418,254,672 \\
(65)\end{array}$ & $\begin{array}{c}-216,222,951 \\
(65)\end{array}$ & $\begin{array}{c}13,618,658,122 \\
(61)\end{array}$ & $\begin{array}{c}78.5 \% \\
(73)\end{array}$ & $\begin{array}{c}10.8 \% \\
(10)\end{array}$ & $\begin{array}{c}4.3 \% \\
(4)\end{array}$ & $\begin{array}{c}3.2 \% \\
(3)\end{array}$ & $\begin{array}{c}3.2 \% \\
(3)\end{array}$ \\
\hline $60-68$ & $\begin{array}{l}5,011 \\
(3)\end{array}$ & $\begin{array}{c}4,953,899,318 \\
(2)\end{array}$ & $\begin{array}{c}261,095,782 \\
(2)\end{array}$ & $\begin{array}{c}5,142,090,643 \\
(2)\end{array}$ & $\begin{array}{c}100.0 \% \\
(3)\end{array}$ & $\begin{array}{c}0.0 \% \\
(0)\end{array}$ & $\begin{array}{c}0.0 \% \\
(0)\end{array}$ & $\begin{array}{c}0.0 \% \\
(0)\end{array}$ & $\begin{array}{c}0.0 \% \\
(0)\end{array}$ \\
\hline
\end{tabular}

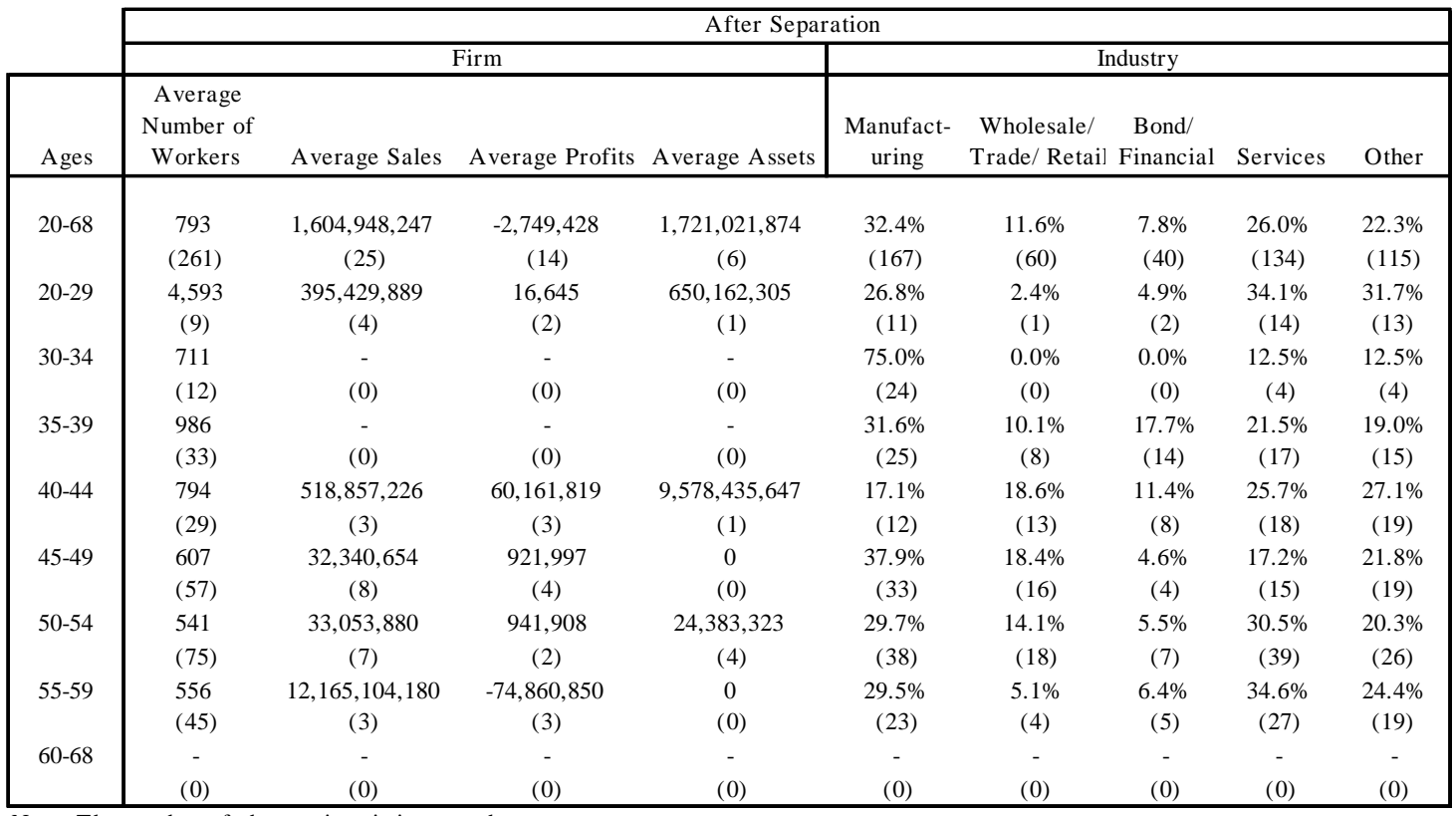

Note: The number of observations is in parentheses. 
Figure 1: Age-Earnings Profiles

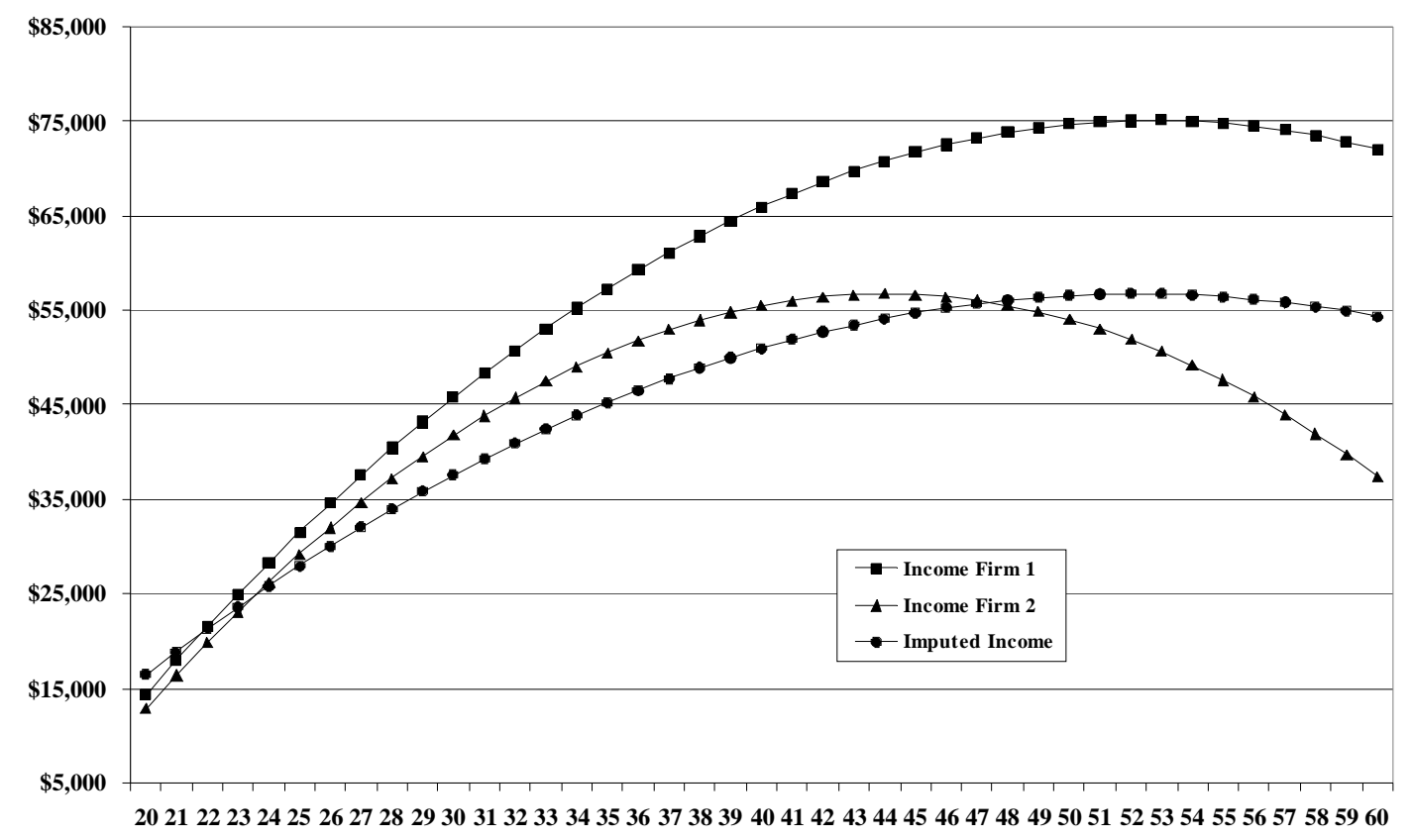


Figure 2: Tenure-Earnings Profile

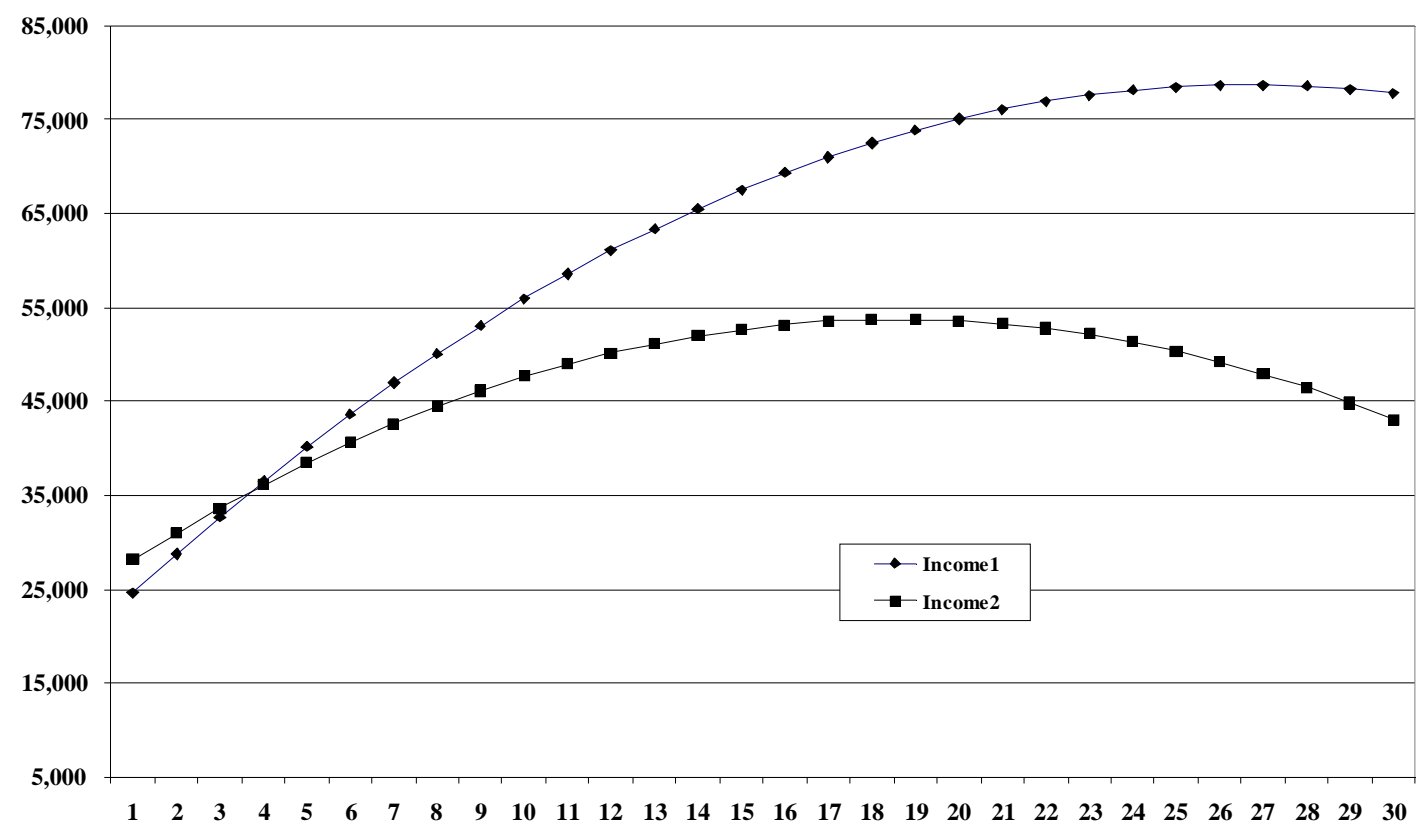


Figure 3: Total Loss in Earnings with Retirement at

Age 60

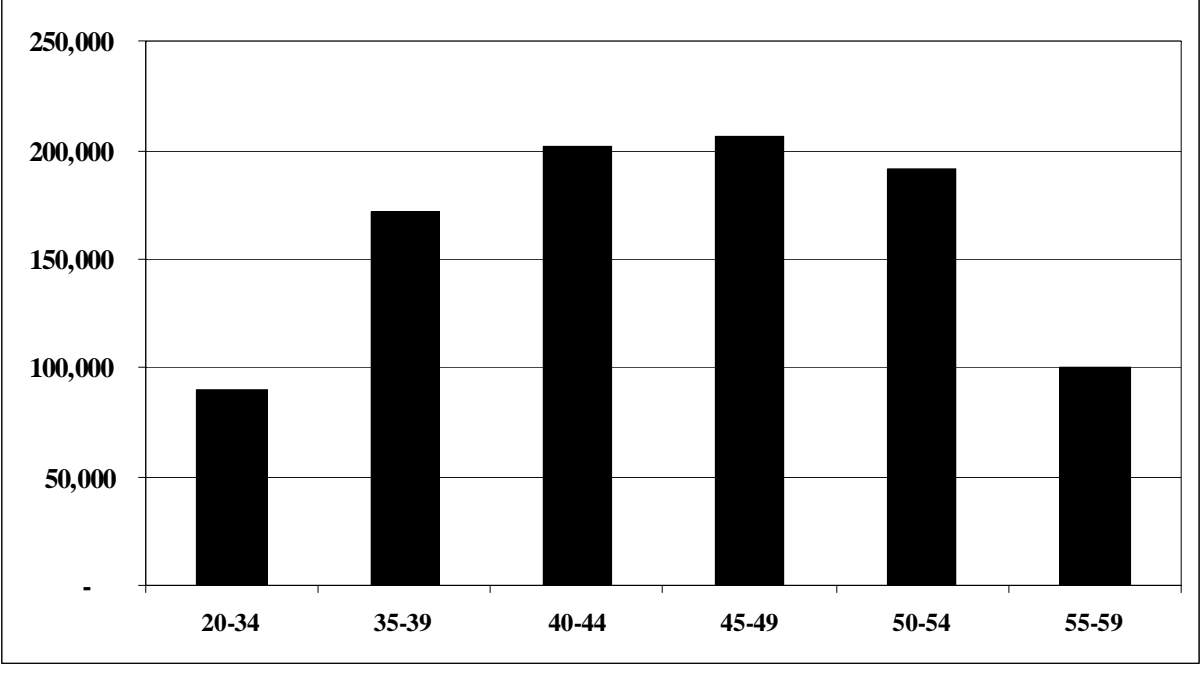


Table 5

\begin{tabular}{|c|c|c|c|c|c|c|c|c|c|c|c|c|}
\hline Dependent Variable: & & & Log In & come1 & & & & & Log Ir & come2 & & \\
\hline Independent Variables & (1) & (2) & (3) & (4) & (5) & (6) & (1) & (2) & (3) & (4) & (5) & (6) \\
\hline Intercept & 8.0140 & 8.1725 & 7.9789 & 8.6887 & 8.0540 & 8.9737 & 7.5639 & 7.7425 & 7.4167 & 8.0383 & 7.5883 & 7.9501 \\
\hline Age $^{2}$ & $\begin{array}{c}-0.0012 \\
(-6.9)\end{array}$ & $\begin{array}{c}-0.0012 \\
(-6.4)\end{array}$ & $\begin{array}{c}-0.0011 \\
(-3.5)\end{array}$ & $\begin{array}{c}-0.0010 \\
(-5.0)\end{array}$ & $\begin{array}{l}-0.0011 \\
(-3.4)\end{array}$ & $\begin{array}{c}-0.0008 \\
(-2.3)\end{array}$ & $\begin{array}{c}-0.0017 \\
(-9.1)\end{array}$ & $\begin{array}{c}-0.0017 \\
(-8.6)\end{array}$ & $\begin{array}{c}-0.0015 \\
(-4.3)\end{array}$ & $\begin{array}{c}-0.0016 \\
(-7.6)\end{array}$ & $\begin{array}{c}-0.0016 \\
(-5.1)\end{array}$ & $\begin{array}{c}-0.0014 \\
(-4.1)\end{array}$ \\
\hline Years of education & & & $\begin{array}{c}0.0188 \\
(1.5)\end{array}$ & & & $\begin{array}{c}-0.0051 \\
(-0.3)\end{array}$ & & & $\begin{array}{c}0.0366 \\
(2.6)\end{array}$ & & & $\begin{array}{c}0.0057 \\
(0.4)\end{array}$ \\
\hline Imputed Tenure & & & & $\begin{array}{c}0.0196 \\
(2.8)\end{array}$ & & $\begin{array}{c}0.0377 \\
(3.2)\end{array}$ & & & & $\begin{array}{c}0.0111 \\
(1.6)\end{array}$ & & $\begin{array}{c}0.0214 \\
(2.0)\end{array}$ \\
\hline Level in Firm 1 Hierarchy & & & & & $\begin{array}{c}0.0184 \\
(1.1)\end{array}$ & $\begin{array}{c}0.0248 \\
(1.4)\end{array}$ & & & & & $\begin{array}{c}0.0360 \\
(2.5)\end{array}$ & $\begin{array}{c}0.0455 \\
(2.7)\end{array}$ \\
\hline Total Obs. & 377 & 370 & 135 & 370 & 110 & 105 & 509 & 500 & 192 & 500 & 175 & 160 \\
\hline
\end{tabular}

Note: t-statistics are in parentheses. 
Table 6

\begin{tabular}{|c|c|c|c|c|c|c|c|c|c|}
\hline \multirow{2}{*}{\begin{tabular}{|c|} 
Dependent Variable: \\
Independent Variables
\end{tabular}} & \multicolumn{9}{|c|}{ Income Change (Income 2 - Income 1) } \\
\hline & (1) & (2) & (3) & (4) & (5) & (6) & (7) & (8) & (9) \\
\hline Intercept & 30597 & -25053 & -19550 & -9243 & -27274 & -19102 & -8385 & -8250 & -2737 \\
\hline Age & $\begin{array}{l}-1110 \\
(-10.7)\end{array}$ & $\begin{array}{l}1678 \\
(1.9)\end{array}$ & $\begin{array}{l}1402 \\
(1.5)\end{array}$ & $\begin{array}{c}696 \\
(0.5)\end{array}$ & $\begin{array}{l}1910 \\
(1.7)\end{array}$ & $\begin{array}{l}1806 \\
(1.0)\end{array}$ & $\begin{array}{l}1171 \\
(1.4)\end{array}$ & $\begin{array}{l}1156 \\
(0.8)\end{array}$ & \\
\hline $\mathrm{Age}^{2}$ & & $\begin{array}{c}-33 \\
(-3.1)\end{array}$ & $\begin{array}{c}-30 \\
(-2.7)\end{array}$ & $\begin{array}{c}-23 \\
(-1.3)\end{array}$ & $\begin{array}{c}-34 \\
(-2.9)\end{array}$ & $\begin{array}{c}-38 \\
(-1.9)\end{array}$ & $\begin{array}{c}-25 \\
(-2.5)\end{array}$ & $\begin{array}{c}-28 \\
(-1.3)\end{array}$ & \\
\hline Gender $($ Female = 1) & & & $\begin{array}{c}-1657 \\
(-0.5)\end{array}$ & $\begin{array}{c}780 \\
(0.2)\end{array}$ & $\begin{array}{l}-1858 \\
(-0.6)\end{array}$ & $\begin{array}{l}-4025 \\
(-0.6)\end{array}$ & $\begin{array}{l}-1255 \\
(-0.4)\end{array}$ & $\begin{array}{r}-1920 \\
(-0.6)\end{array}$ & \\
\hline Employment Firm 1(1000s) & & & & $\begin{array}{l}-0.18 \\
(-1.3)\end{array}$ & $\begin{array}{l}-0.14 \\
(-1.3)\end{array}$ & $\begin{array}{l}-0.20 \\
(-1.1)\end{array}$ & $\begin{array}{l}-0.18 \\
(-1.9)\end{array}$ & $\begin{array}{l}-0.15 \\
(-1.1)\end{array}$ & \\
\hline Years of education & & & & $\begin{array}{c}459 \\
(0.6)\end{array}$ & & & & & \\
\hline Imputed Tenure & & & & & $\begin{array}{c}-271 \\
(-0.6)\end{array}$ & & & & \\
\hline Level in Firm 1 Hierarchy & & & & & & $\begin{array}{c}-283 \\
(-0.3)\end{array}$ & & & \\
\hline Days of Unemployment & & & & & & & $\begin{array}{c}-45 \\
(-3.8)\end{array}$ & $\begin{array}{c}29 \\
(0.2)\end{array}$ & \\
\hline Change of Industry & & & & & & & $\begin{array}{l}-5086 \\
(-2.8)\end{array}$ & $\begin{array}{c}-10636 \\
(-0.5)\end{array}$ & \\
\hline Ages 35-39 & & & & & & & & & $\begin{array}{r}-7466 \\
(-2.2)\end{array}$ \\
\hline Ages 40-44 & & & & & & & & & $\begin{array}{c}-11219 \\
(-3.1)\end{array}$ \\
\hline Ages 45-49 & & & & & & & & & $\begin{array}{r}-15868 \\
(-4.4)\end{array}$ \\
\hline Ages 50-54 & & & & & & & & & $\begin{array}{r}-23996 \\
(-7.4)\end{array}$ \\
\hline Ages 55-59 & & & & & & & & & $\begin{array}{c}-33629 \\
(-9.4)\end{array}$ \\
\hline R-Square & 0.25 & 0.27 & 0.27 & 0.38 & 0.32 & 0.40 & 0.36 & 0.30 & 0.27 \\
\hline Total Obs. & 341 & 341 & 334 & 114 & 311 & 91 & 311 & 311 & 341 \\
\hline
\end{tabular}

Notes:

1. t-statistics are in parentheses.

2. Column 8 is estimated with two-stage least squares, days of unemployment and industry change are instrumented with the monthly unemployment rate and imputed tenure. 
Table 7: Firm 1 Fixed Effect Models

\begin{tabular}{|c|c|c|c|c|c|c|c|c|c|c|c|c|}
\hline \multirow{2}{*}{\begin{tabular}{|l} 
Dependent Variable: \\
Independent Variables
\end{tabular}} & \multicolumn{6}{|c|}{ Log Income1 } & \multicolumn{6}{|c|}{ Log Income2 } \\
\hline & (1) & (2) & (3) & (4) & (5) & (6) & (1) & (2) & (3) & (4) & (5) & (6) \\
\hline Age & $\begin{array}{c}0.0948 \\
(6.7)\end{array}$ & $\begin{array}{c}0.0878 \\
(6.0)\end{array}$ & $\begin{array}{c}0.0922 \\
(3.5)\end{array}$ & $\begin{array}{c}0.0496 \\
(2.8)\end{array}$ & $\begin{array}{c}0.0902 \\
(3.2)\end{array}$ & $\begin{array}{c}0.0304 \\
(0.8)\end{array}$ & $\begin{array}{c}0.1347 \\
(8.1)\end{array}$ & $\begin{array}{c}0.1270 \\
(7.5)\end{array}$ & $\begin{array}{c}0.1213 \\
(3.9)\end{array}$ & $\begin{array}{c}0.1103 \\
(5.3)\end{array}$ & $\begin{array}{c}0.1371 \\
(4.4)\end{array}$ & $\begin{array}{c}0.1039 \\
(2.8)\end{array}$ \\
\hline $\operatorname{Age}^{2}$ & $\begin{array}{c}-0.0009 \\
(-5.2)\end{array}$ & $\begin{array}{c}-0.0008 \\
(-4.7)\end{array}$ & $\begin{array}{c}-0.0008 \\
(-2.6)\end{array}$ & $\begin{array}{c}-0.0005 \\
(-2.9)\end{array}$ & $\begin{array}{c}-0.0008 \\
(-2.3)\end{array}$ & $\begin{array}{c}-0.0004 \\
(-1.0)\end{array}$ & $\begin{array}{c}-0.0016 \\
(-7.9)\end{array}$ & $\begin{array}{c}-0.0015 \\
(-7.4)\end{array}$ & $\begin{array}{c}-0.0014 \\
(-3.7)\end{array}$ & $\begin{array}{c}-0.0014 \\
(-6.3)\end{array}$ & $\begin{array}{c}-0.0015 \\
(-4.2)\end{array}$ & $\begin{array}{c}-0.0013 \\
(-3.2)\end{array}$ \\
\hline Gender (Female = 1) & & $\begin{array}{c}-0.1668 \\
(-3.2)\end{array}$ & $\begin{array}{c}-0.0699 \\
(-0.7)\end{array}$ & $\begin{array}{c}-0.1177 \\
(-2.2)\end{array}$ & $\begin{array}{c}0.0694 \\
(0.6)\end{array}$ & $\begin{array}{c}0.0998 \\
(0.9)\end{array}$ & & $\begin{array}{c}-0.1455 \\
(-2.6)\end{array}$ & $\begin{array}{c}-0.0839 \\
(-0.8)\end{array}$ & $\begin{array}{c}-0.1166 \\
(-2.0)\end{array}$ & $\begin{array}{c}-0.0126 \\
(-0.1)\end{array}$ & $\begin{array}{c}0.0493 \\
(0.4)\end{array}$ \\
\hline Imputed Tenure & & & & $\begin{array}{c}0.0268 \\
(3.5)\end{array}$ & & $\begin{array}{c}0.0463 \\
(3.3)\end{array}$ & & & & $\begin{array}{c}0.0117 \\
(1.4)\end{array}$ & & $\begin{array}{c}0.0218 \\
(1.5)\end{array}$ \\
\hline Level in Firm 1 Hierarchy & & & & & $\begin{array}{c}0.0061 \\
(0.4)\end{array}$ & $\begin{array}{c}0.0108 \\
(0.6)\end{array}$ & & & & & $\begin{array}{c}0.0300 \\
(1.9)\end{array}$ & $\begin{array}{c}0.0318 \\
(1.7)\end{array}$ \\
\hline
\end{tabular}

Note: t-statistics are in parentheses. 
Table 8: Firm 1 Fixed Effect Models

\begin{tabular}{|c|c|c|c|c|c|c|c|c|}
\hline \multirow{2}{*}{\begin{tabular}{|l} 
Dependent Variable: \\
Independent Variables
\end{tabular}} & \multicolumn{8}{|c|}{ Income Change (Income 2 - Income 1) } \\
\hline & (1) & (2) & (3) & (4) & (5) & (6) & (7) & (8) \\
\hline Age & $\begin{array}{l}-1090 \\
(-10.1)\end{array}$ & $\begin{array}{l}2237 \\
(2.5)\end{array}$ & $\begin{array}{l}2177 \\
(2.4)\end{array}$ & $\begin{array}{l}1727 \\
(1.2)\end{array}$ & $\begin{array}{l}3213 \\
(2.8)\end{array}$ & $\begin{array}{l}2855 \\
(1.5)\end{array}$ & $\begin{array}{l}1790 \\
(2.1)\end{array}$ & \\
\hline Age $^{2}$ & & $\begin{array}{c}-40 \\
(-3.7)\end{array}$ & $\begin{array}{c}-38 \\
(-3.5)\end{array}$ & $\begin{array}{c}-34 \\
(-1.9)\end{array}$ & $\begin{array}{c}-45 \\
(-3.9)\end{array}$ & $\begin{array}{c}-50 \\
(-2.2)\end{array}$ & $\begin{array}{c}-33 \\
(-3.2)\end{array}$ & \\
\hline Gender (Female = 1) & & & $\begin{array}{l}4418 \\
(1.4)\end{array}$ & $\begin{array}{l}3447 \\
(0.6)\end{array}$ & $\begin{array}{l}2978 \\
(0.9)\end{array}$ & $\begin{array}{c}178 \\
(0.0)\end{array}$ & $\begin{array}{l}4122 \\
(1.3)\end{array}$ & \\
\hline Employment Firm 1(1000s) & & & & $\begin{array}{c}-0.26 \\
(-1.3)\end{array}$ & $\begin{array}{l}-0.21 \\
(-1.5)\end{array}$ & $\begin{array}{l}-0.34 \\
(-1.2)\end{array}$ & $\begin{array}{l}-0.25 \\
(-1.9)\end{array}$ & \\
\hline Years of education & & & & $\begin{array}{c}602 \\
(0.7)\end{array}$ & & & & \\
\hline Imputed Tenure & & & & & $\begin{array}{c}-827 \\
(-1.7)\end{array}$ & & & \\
\hline Level in Firm 1 Hierarchy & & & & & & $\begin{array}{c}-156 \\
(-0.1)\end{array}$ & & \\
\hline Days of Unemployment & & & & & & & $\begin{array}{c}-24 \\
(-1.9)\end{array}$ & \\
\hline Change of Industry & & & & & & & $\begin{array}{l}-3975 \\
(-2.3)\end{array}$ & \\
\hline Ages 35-39 & & & & & & & & $\begin{array}{l}-1363 \\
(-0.4)\end{array}$ \\
\hline Ages 40-44 & & & & & & & & $\begin{array}{l}-5350 \\
(-1.5)\end{array}$ \\
\hline Ages 45-49 & & & & & & & & $\begin{array}{c}-16477 \\
(-4.6)\end{array}$ \\
\hline Ages 50-54 & & & & & & & & $\begin{array}{c}-23064 \\
(-7.1)\end{array}$ \\
\hline Ages 55-59 & & & & & & & & $\begin{array}{c}-28968 \\
(-8.1)\end{array}$ \\
\hline R-Square & 0.50 & 0.52 & 0.52 & 0.58 & 0.52 & 0.61 & 0.53 & 0.51 \\
\hline Total Obs. & 341 & 341 & 334 & 114 & 311 & 91 & 311 & 341 \\
\hline
\end{tabular}

Note: t-statistics are in parentheses. 